\title{
Computerized role models
}

\section{Japan's push to create a virtual cell signals a new approach to research, says Robert Triendl.}

n many ways, the year-old Institute for Advanced Biosciences at Keio University in Tsuruoka is an anomaly of Japanese science. It is run by a relatively young scientist, uses short-term appointments, and it gives its junior faculty members a great deal of academic freedom.

The institute was established last year with a grant from the Yamagata prefecture with additional funding from Keio University, Japan's top-ranked private university. It is built around E-CELL, an ambitious idea by its director, Masaru Tomita, to develop a realistic computer simulation of an entire living cell.

Tomita trained as a computer scientist at Keio and at Carnegie Mellon University in Pittsburgh, where he also worked for several years as an assistant professor. After he returned to Japan in the early 1990s, his group at Keio's Fujisawa campus, along with scientists at The Institute of Genomic Research in Rockville, Maryland, completed the first 'virtual cell' in 1997, based on the workings of 127 'virtual' genes selected from the genome of the bacterium Mycoplasma genitalium.

Tomita quickly recognized that to build better models, he needed more data. But as such data were not available, there was little he could do except build the data sets on his own. His chance came when the Yamagata prefecture approached Keio University with the proposal to set up a campus in Tsuruoka.

\section{DATA HUNTING}

At the Institute for Advanced Biosciences, Tomita has assembled a research team that covers a broad range of specialisms, including enzyme engineering, analytical chemistry, genetic engineering, computer sciences and mathematics. Although most of the scientists have a background in molecular biology or biochemistry, work at the institute is orientated towards creating realistic computer models of living cells.

Today, there are about 30 scientists and roughly the same number of graduate students working at the institute. Most of the staff scientists are younger researchers in assistant-professor positions. All appointments, including Tomita's own as director,

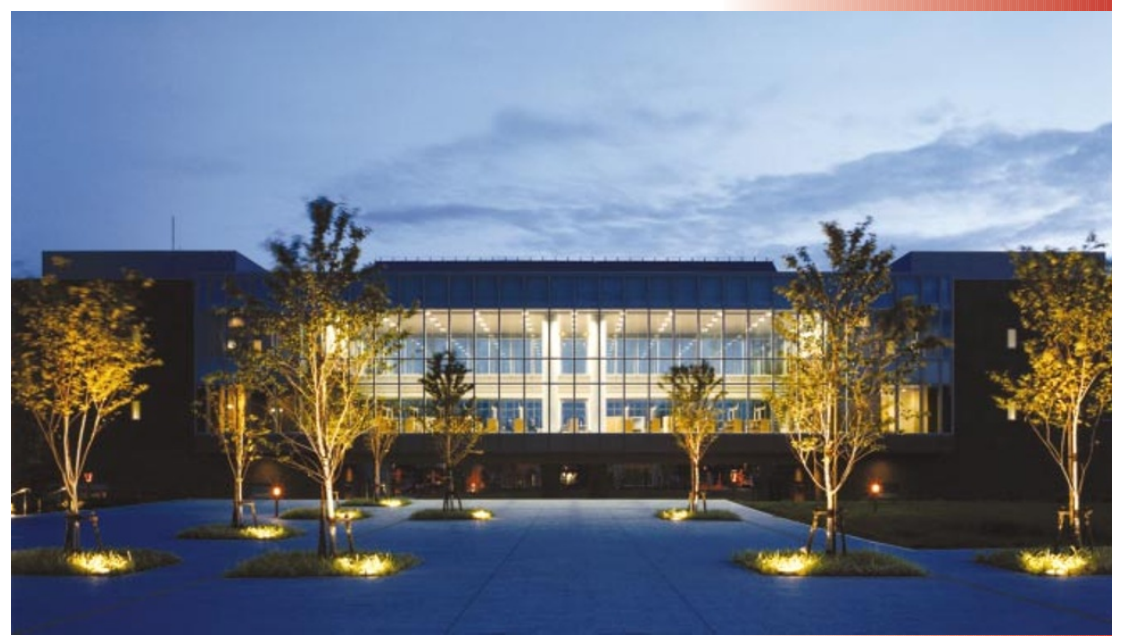

are renewable after three years.

Although this policy is still unusual in a country with an extremely tight academic labour market, Tomita says he voted for it despite the university's reservations. "Three years is a short period of time, but I think it's a good incentive," he says. "More importantly, a limited-term contract provides young scientists with much more freedom than a tenured faculty position. There is nobody who tries to control you." Nevertheless, many of the senior staff hold joint appointments at other parts of the university.

Already, most of the institute's research funding comes through grants from agencies in Tokyo. On a project financed by the New Energy Development Organization, scientists at the institute will develop general quantitative models to simulate cell metabolism in Escherichia coli. The long-term goal of this five-year project is to develop tools for the engineering and design of microorganisms for industrial applications. Research on the simulation of metabolism in rice is funded by, and undertaken in cooperation with, the rice genome project at the agriculture ministry.

And today, E-CELL is not the isolated project it was a few years ago. "When I started the E-CELL project some six years ago, I would estimate that $99 \%$ of bioscientists in Japan did not take my work seriously," recalls Tomita. "Today I would estimate that number at below 50\%." As that number declines, the prospects for fresh ways of organizing and running research institutions continue to improve.

Robert Triendl is a freelance writer based in Tokyo.

Institute for Advanced Biosciences www.ttck.keio.ac.jp/IAB

E-CELL www.e-cell.org
Virtual world: researchers at the Institute for Advanced Biosciences aim to generate accurate computer models of living cells. 